\title{
Questions of Female Gaze: Males Through Eyes of Females in Vijay Tendulkar's Select Plays
}

\section{Tamal Ghsoh}

Assistant Professor

Rishi Bankim Chandra College for Women

Kolkata, West Bengal, India

tgghosh88@gmail.com

Abstract

Gaze, as defined by Oxford Advance learner's Dictionary, “is an interested steady look at something or somebody" (642). The privilege of gazing presupposes or attributes some power in the onlookers. So, gaze is an expression of power, a way of looking, a point of view or a medium to establish and extend dominance. In a patriarchal set-up of society, the role of the onlooker is played most of the times by males, and according to Laura Mulvey, women are generally made to appear as the visual sex objects of male desire and pleasure. Here, my question is, do the females dare to return the male gaze in one way or another?

I want to dwell upon the possibility of a reversed or altered picture of male gaze in the context of Tendulkar's plays. So, let the females be the gazers and males be the gazed in the context of Tendulkar's selected plays and let me make an attempt to study certain male characters as looked by certain female figures. Champa and Laxmi in Sakharam Binder, Leela Benare and Mrs. Kashikar in Silence! the Court is in Session and Sarita and Kamala in Kamala represent a polarity of 'female eyes'. Champa, Leela Benare, and Sarita take guts to have a gaze at the body, activity, and position of their chauvinistic male counterparts and often, put a question mark to the so-called vanity of masculinity. But Laxmi, Mrs. Kashikar, and Kamala look at men in the way men want to be looked at with all of his power over them. 
In view of the above, I shall try to show whether there is a scope for an active female gaze? If yes, to what extent? Do they transgress their traditional roles imposed on them in returning the male gaze and open up a space for anti-male discourse?

Keywords: Patriarchy, Male Gaze, Masculinity, Femininity, Female Gaze, Anti-male Discourse

In an excerpt entitled "The Play is the Thing" taken from the Tenth Sri Ram Memorial Lecture (1997), Vijay Tendulkar said that his characters were the backbone of his plays (2), and admitted further that he had never been able to begin writing his play only with an idea or a theme in mind (15). Such statements are clear clues to make us realize what an important role his characters play in his plays, and how the study of characters can interestingly reveal and expose so many layers of meanings. Characters are best understood in totality-with their virtues and vices - with their subtle shades of nuances both in reality and appearance, when they are perceived and represented in one-another's visions. This necessarily takes into account the gaze of both male and female in relation to their counterparts and the issues of emmasculation - the state of making women powerless in projecting their gaze and regulate the representation of men in their perception and vision.

Tendulkar had never been a self-proclaimed a feminist. But from his delineation of the sufferings and misery of the women folks in the hands of males in the fabric of manwoman relationships, it seems certain that he sympathizes with the plight and predicament of women. He gives women a voice as well as a vision to counter the patriarchal power structure where exploitation both physical and mental, is continuously carried out by typecasting the women as inferior and dependent folks with an innocent look, vulnerable body and with no authority to exercise and or/ exalt their power over masculine pre-eminence. However, Tendulkar's women characters like Champa or Leela Benare come strongly with a threat to knock down and eradicate the age-old binary oppositions between male and female in the 
post-independent India and demand to be recognized and identified with some male attributes like being unconventional, clever, stubborn, rebellious, and grasping. The late impact of the social reform movement of the nineteenth century; the revival of glorification of the women's traditional role as the nurturer of the family from the pre-independent feudal society; and the complaints of Jyotiba Phooley that women suffer because of the patriarchal construction of family and marriage in Indian society are to some extent responsible for bringing up that change. Apart from these socio-cultural upheavals that shaped Tendulkar's viewpoints quite revolutionary and reactionary to the established norms, we can, here, mention the upbringing of child Tendulkar who had long been dressed like a girl and who had seen his mother, Susheela threatened and rebuked by his menacing father. So, personally, he felt a necessity of building up a female gaze point and walked a path different from the one to be found in the Ways of Seeing by John Berger: "Men act and women appear. Men look at women. Women look themselves being looked at" (47).

Laura Mulvey's Visual Pleasure and Narrative Cinema is the first article to introduce the concept of male gaze and connect it to scopophilia, a kind of erotic pleasure that men derive by ogling at stimulating objects especially women. However, when she is asked about the female gaze, she says that, if female gaze is ever possible it is only through male identification. What she means is that when females look at males, the surveyors in them are actually males because the social structure is such. John Berger also comments in the same way: "The surveyor of woman in herself is male: the surveyed female. This she turns herself into an object----and most particularly an object of vision: a sight" (47).

This paper as proposed earlier will focus on the fictional oeuvre of Tendulkar with a view to negotiate the masculine and feminine nature of female gaze through a study of character oriented gaze. Let us start with Sakharam Binder. It opens with a harangue which tells us what sort of man Sakharam is in his own terms. In short, he is a womanizer, drunkard 
and disbeliever in the institution of marriage. He picks up cast off women, gives them food and shelter, and in exchange, the women are expected to satisfy all kinds of needs demanded by a husband from a wife. Laxmi and Champa are such two women in the life of Sakharam Binder. Another male figure in the play is Dawood Miyan, a friend of Sakharam who is actually a person always on the lookout of having some voyeuristic pleasure on the body of Sakharam's purchased women. From the very beginning of the play Laxmi's gaze which is directed downwards is suggestive of the blinders or blinkers that patriarchy has made them to wear to affect or control their vision. When she is advised what to do and what not to do in the house, she only listens without looking anywhere. Or when she is pressings the legs of Sakharam on the mattress, though Sakharam is watching her sexually Laxmi shies to contact her eyes with Sakharam and looks down. She is afraid of being seen with Sakharam intimately by somebody. She does not want to be beaten in front of the image of God. Referring to the concept of 'Panopticon or all seeing' by Michel Foucault it may be said that women think that they are always under the all controlling web of male gaze. But when the torture of Sakharam reaches to an intolerable height, Laxmi backs her identity and negates what she is taken for granted. Instead she asserts that she is neither a slut nor a bitch no a niggling bit of a cast-off woman.

Champa, a wife of Police Fouzdar enters the drama in the second act and dominates the scenes until her death. Champa when sets foot in Sakharam's house, she is told not to look up and talk to anybody. Nevertheless, she begins to question the kingship of Sakharam in his house. Champa seems to objectify his husband when she describes how her marriage had taken place. Sakharam kept on begging to marry him, and she married him not out of love but to avoid such type of nagging nuisance. Champa calls Dawood a 'pet', taunts him by using using the adjective, 'nice' with sexual connotations to the utter jealousy of Sakharam and smiles bewitchingly at him. When Champa goes to change her sari, Sakharam and 
Dawood were having a scopophilic pleasure looking at Champa. Champa, on the other side, unlike a traditional woman, remains unmindful of her sexual difference and does not express any kind of sexual inhibitions. Rather, she remains unashamed of her nudity and sexuality. In her eye, both Dawood and Sakharam appear as a pimp, a client or a degraded being. Her feminine fantasy makes her invite any customer to have fun considering them as 'corpse' or 'dog'. Champa questions Sakharam's sexual potency, and alleges that the re-entry of Laxmi in their conjugal life made Sakharam unworthy to be taken on anymore. He has become a ninny, and that's why she starts a sexual game with Dawood in expectation of more than what Sakharam can give to her. Whether it is Laxmi or Champa - when they start looking, the males feel castration issue and their rising gas is blinded with hard hands. As a result of that, towards the end of the play, Champa is strangled to death.

In Silence the Court is in Session Leela Benare is taken to the dock, though playfully, there is a subtle plan of placing her in front of collective male gaze for some pleasure and unveil her private life in the public eye. Benare was in love with her maternal uncle, and offered her body on the altar of her worship Prof. Damle. Now, in order to save her baby in the womb and her prestige, she tries to get closer to Samant, to get married to Ponkshe or to be intimate with Balu Rokde with a view to getting a father of her baby within the institution of marriage. For, she is thought to have committed a sin against her body by involving in sexual morality, and a baby born out of this body is considered illegal and unacceptable in a society. Thus towards the end of the drama, her comment on 'body' seems interesting. Body to her is an object of both love and hatred. 'Body' once gave her a beautiful and blissful moment in the hands of patriarchy, and she enjoyed that bodily exchange and unison. But, once she comes to bear the brunt of her bodily sin, she starts having feminine anxiety over public honour. Her thinking psyche gets masculinized. She wants to have a baby boy, another heir to patriarchy. 
As a teacher, Benare can keep her eye on the whole class. But, what about his fellow actors and Samant, the village boy? In this case, she develops a gaze that penetrates into the pretensions of patriarchy. All of her co-artists, in her vision, represent an unfulfilled dream and the psychology of frustrated lots. For instance, Sukhatme is a poor barrister. Ponkshe is only an inter -failed scientist. Karnik is a failed actor. Prof. Damle is a coward, 'a poor cat in the adage'. Benare's loyal and innocent pupils are much better than these guys. At least they don't have that blind pride of thinking that they know everything. There is no nonsense stuffed in their heads. They don't scratch one till one bleeds or run away like cowards.

Kamala is all about the earning of reputation in journalism in exchange of showcasing a woman bought from flesh market. Jaisingh Jadav is happily married to Sarita, but the entry of Kamala in their house brings some unconventional changes in Sarita's psyche and vision. She begins to question the objectification of women and the masterly rule over women. But Kamala, on the other hand, expresses her desire to produce a child by Jaisingh when the marital status of Sarita and Jaisingh bears no fruit. So, in a way she is objectifying the male body. The objectification of the male body, here, happens, not merely because of the sexual pleasure that it elicits, but because of the fact that instates the participation of the male partner is necessary for continuing the child producing mechanism in a society. In case of Champa or Kamala, they are roofless and helpless, and needs a partner who they think would feed them in exchange of sexual intercourse. Champa surrenders her body to Sakharam when she is drunk. Her liaison with Dawood in expectation of plentiful sexual gratification reveals the impotence of male power. However, for Benare the body which gave her lovely moments becomes a concern. To give her body a meaning she struggles to search for a male.

Another feature of female gaze is suggested by Jennifer Friedlander in her Feminine Look: Sexuation, Spectatorship, Subversion where she connects a woman's pleasure, not with sexuality, but with an attempt of escape from the system of patriarchal power in order to be 
her own on its own feminine standard. For example, in Sakharam Binder, Champa denies Sakharam an easy access to her body until she is drunk and unconscious. But whenever she is conscious, she is all she with the assertion of her powerful self, beats her husband black and blue and orders Sakharam to prepare her tea. For Benare her life is her own, her wishes are her own. She is the owner of her life and no one has the legal right to interfere and hold an inquiry just because of 'one bit of slander'. Thus she throws a fearless challenge: 'What can they do... Who are these people to say what I can and can't do' (Tendulkar 5; Act I). Sarita in Kamala for a while becomes defiant and advocates for the cause of Kamala. She threatens to unmask Jaisingh naked in public domain. Sarita who wants to see a woman with manly power, right and sense, bears a masculine-feminine gaze:

Why? Why men can't limp behind? Why aren't women ever the masters? Why can't a woman at least ask to live her life the same way as a man? Why must only a man have the right to be a man? Does he have one sense? A woman can do everything a man can (Tendulkar 47; Act II).

Therefore, she hopes a day will come when she will stop being a slave and an object.

The other set of women in these plays internalizes the dominance of men over them as a natural phenomenon and thereby goes to safeguard patriarchy. Foucault in Power/Knowledge articulates that male is exercised and strengthened by a net like organization and by the prescription of some disciplines which not only limit their power and vision, but also force to adapt to the male point of view of looking and seeing men. Laxmi takes Sakharam as her saviour, king, and God. It reminds us of Miltonic line, "He for god only she for God in him" (299) . Perhaps, in a male dominated society women are always the servant to their husband gods. Even when Sakharam kills Champa, Laxmi comes to cover up the wrong deeds of Sakharam. Mrs. Kashikar thinks her husband as a man with the automatic 
power to insult and silence her whenever he whims. Sarita who seems to be a rebel comes to be siding with Jaisingh when he is sacked.

To conclude, it may be said that the presentation of a couple of women in the aforementioned plays is very purposive. For it offers two contrasting ways of looking and thereby heightens the effect. Mrs. Kashikar and Laxmi see men from a stereotypical feminine point of view that justifies man with all its manliness, power and authority. But Champa, Benare, and Sarita open up a space for an alternative discourse which is anti-male in the sense that they transgress the traditional concept of woman and wife, and enjoy some pleasure in being rebellious and in trying to break apart the system of power. These women though perform the conventional role of wives for the maximum time, occasionally they come forward with their strong masculine perspective to pay back men on their own coin, and often with a way of seeing which is neither masculine nor feminine, but is very characteristic of their being, becoming and belonging. 


\section{Works Cited}

Primary Source:

Tendulkar, Vijay. Five Plays. Translated by Priya Adarkar, Kumud Mehta and Shanta Gokhale, Oxford University Press, 1992.

Secondary Source:

Berger, John. Ways of Seeing. BBC and Penguin Books, 1972.

Foucault, Michel. Power/Knowledge: Selected Interviews and Other Writings 1972-1977. Translated by Colin Gordon, Leo Marshall, et al., Pantheon Books, 1980.

Friedlander, Jennifer. Feminine Look: Sexuation, Spectatorship, subversion. State University of New York Press, 2008.

Milton, John. Paradise Lost. Introduced by Philip Pullman, Oxford University Press, 2005.

Mulvey, Laura. Visual Pleasure and Narrative Cinema. Macmillan, 1989.

Tendulkar, Vijay. "The Play is the Thing." Sri Ram Memorial Lecture X. Sri Ram Centre For Performing Arts, 1997. 